talêto

\title{
Impact of Supply Chain Integration on Business Performance: A Review
}

\author{
Donald Robert Manik ${ }^{1}$, Sukaria Sinulingga ${ }^{2}$, Aulia Ishak ${ }^{3}$ \\ 1,2,3 Department of Industrial Engineering, Universitas Sumatera Utara, Medan, Indonesia
}

\begin{abstract}
Supply Chain method approach has become a resource for companies to build a sustainable competitive advantage in this complex and volatile competitive environment. Numerous recent literature studies on supply. However, comprehensive analysis, clearly identifying the supply chain relationships used and finding the impact of this relationship on supply chain performance are still lacking. Therefore, this research has the main objective to review past studies on the implementation of supply chain in SMEs, as well as to research the literature to analyze how SMEs have implemented supply chain management approaches. To understand the role of supply chains in SMEs conducted a comprehensive literature review, which resulted in the identification and analysis of 20 high quality international journal articles, published between 2017 and 2021 in English. Based on the findings from this literature review, there are methods or frameworks that can be used by researchers to understand the implementation of Supply Chain Integration in business that can improve performance, efficiency, added customer value, or even competitive advantage. Then, the researcher realizes the need to conduct a literature review to see new developments and findings that have appeared in previous studies. The result is a detailed analysis of the main findings and insights obtained.
\end{abstract}

Keyword: Supply Chain, Small Medium Micro Enterprises (SMEs), Performance

\begin{abstract}
Abstrak. Pendekatan metode Supply Chain telah menjadi sumber daya bagi perusahaan untuk membangun keunggulan kompetitif yang berkelanjutan dalam lingkungan persaingan yang kompleks dan bergejolak ini. Banyak studi literatur baru-baru ini tentang pasokan. Namun, analisis yang komprehensif, dengan jelas mengidentifikasi hubungan rantai pasokan yang digunakan dan menemukan dampak dari hubungan ini pada kinerja rantai pasokan masih kurang. Oleh karena itu, penelitian ini memiliki tujuan utama untuk meninjau studi masa lalu tentang implementasi rantai pasokan di UKM, serta untuk meneliti literatur untuk menganalisis bagaimana UKM telah menerapkan pendekatan manajemen rantai pasokan. Untuk memahami peran rantai pasokan dalam UKM, dilakukan tinjauan literatur komprehensif, yang menghasilkan identifikasi dan analisis 20 artikel jurnal internasional berkualitas tinggi, yang diterbitkan antara 2017 dan 2021 dalam bahasa Inggris. Berdasarkan temuan dari tinjauan pustaka ini, terdapat metode atau framework yang dapat digunakan peneliti untuk memahami implementasi Supply Chain Integration dalam bisnis yang dapat meningkatkan kinerja, efisiensi, nilai tambah pelanggan, atau bahkan keunggulan kompetitif. Untuk artikel ini, peneliti menyadari perlunya melakukan tinjauan pustaka untuk melihat perkembangan dan temuan baru yang muncul pada penelitianpenelitian sebelumnya. Akhirnya, analisis rinci dari temuan utama dan wawasan yang diperoleh disajikan dalam makalah ini.
\end{abstract}

Kata Kunci: Supply Chain, Usaha Kecil dan Menengah, Kinerja

Received 22 November 2021 | Revised 06 January 2022 | Accepted 10 January 2022

${ }^{*}$ Corresponding author at: Jl. Almamater, Universitas Sumatera Utara, 20155, Medan, Indonesia

E-mail address: donaldrm2021@gmail.com

https://doi.org/10.32734jsti.v24i1.7621 Attribution-NonCommercial-ShareAlike 4.0 International License. Some rights reserved Copyright @ 2022 Published by Talenta Publisher, ISSN: 1411-5247 e-ISSN: 2527-9408

Journal Homepage: http://talenta.usu.ac.id/jsti 


\section{Introduction}

In a more complex and competitive environment, the Supply Chain Management approach has become an important way to build a sustainable competitive advantage. Relationship management in the supply chain that ranges from the first raw material supplier to the end customer can be defined Supply Chain Management (SCM). The main paradigm shift brought about by this approach is that competition is now taking place between chains and no longer between individual firms [1].

In each chain, the keyword is integration, collaboration and trust. Increasingly fierce competition requires companies to be competitive. Companies, through the search for management and technology innovation, will be able to identify strengths and weaknesses, to advantage competitive [2]. The competitiveness of micro and small enterprises (MSEs) also relies heavily on government efforts to promote policies that effectively address the specific needs of this organization. While the current focus of research at SC is on large enterprises, discussions about applying this approach to micro, small and medium enterprises (SMEs) have gained more space [3].

In addition to large companies that rely on some SMEs, which usually act as first or second-tier assistants or suppliers of large companies. The survival of SMEs depends heavily on their ability to increase their productivity at a lower cost, in a short time and with better quality, and the key is effective supply chain management [4].

Kot et.al [5] showed that competition means companies must reduce costs, delivery times, stocks and prices while increasing adaptability, flexibility and agility, so the SC considers strategic importance for SMEs. However, Small and Medium Enterprises are also part of this new hypercompetitive environment, and have considered implementing the SC's approach as a possibility to gain a competitive advantage. The analysis of supply chain management by SMEs will be carried out by analyzing the literature on the following topics (1) the motivation to implement expected supply chain management and benefits; (2) the impact of supply chain management on the performance of SMEs; (3) the challenges and risks of implementation.

The supply chain is not just a supply and distribution chain, it is a major business and relationship network. Some authors confirm that the concept of SC is associated with the movement of goods from the initial stage (original supply) of raw materials to the final stages of the product or service (consumer). In this regard, the primary responsibility of Supply Chain Management is the integration of key business functions and business processes within and between organizations, in a strong and high-performance business model. [5]. Completing this argue, Rezaei and Ortt [6] stated that the main objective of SC is to serve end users and other stakeholders in the most efficient and effective way, with products or services with higher value added and produced at the lowest cost.

Therefore, it is clear that in Supply Chain Management, a collaborative structure integrated with business processes is essential for the selection of the right partner, in the pursuit of excellence in 
terms of product or service. The idea is that chain members are operationally strong and flexible to adapt to consumer demands. Inter-partner relationship factors, called partner company selection, information integration and sharing, joint performance appraisal, and inter-company relationship building, are essential to enable positive performance outcomes. [7]. However, there are some difficulties in approaching and connecting due to the size and importance of the company in the chain.

Furthermore, this research addresses the following questions:

1. What are the benefits of Supply chain for productivity improvements and performance?

2. What techniques to support the integration of Supply chain on SMEs performance?

3. What are the approaches to implement Supply chain?

According to Chopra \& Kaur [8], some SC practices that are widely discussed, such as outsourcing, logistics operators and e-procurement are relatively few used by SMEs. For this reason, this article tries to analyze the application of the SC method and its approach method, within MSMEs, through a literature review survey of 20 articles.

This research contributes to the literature in offering an overview of supply chain relationships in a more systematic way. Understand what has been implemented in terms of supply chain relationships in M/SMEs. This research particularly important as present the information on the effect and impact of supply chain management integration on M/SMEs performance. Also, this research is essential to examine how an effective supply chain can improve the quality of delivery of goods and services by M/SMEs.

\section{Theoretical Review}

Hamiza and Isoh [9] have defined supply chain management (SCM) as a physical, informational and financial act within an organization that seeks to address consumer demand and thereby improve the overall related supply chain. A supply chain can be described as an organization that can engage in a process of different services and products for customers.

Therefore, a supply chain consists of several companies, including suppliers, distributors, and end customers. There are certain goals to be achieved in supply chain management, which are to increase customer satisfaction and service and increase competitiveness. [10].

The main objective of SCM is to regulate flow of products from supplier to end consumer. SCM is also responsible for all processes that take place along the supply chain to maintain competitiveness. Its main objective is to ensure efficient and efficiency delivery of supplier to consumer [11]. The main functions and responsibilities of supply chain management are environmental performance, quality control of supplier goods and services (inventory), and delivery time management and product quality improvement offered by companies [12]. 
Supply chain management is a truly topical topic that, if understood and used in the right way, bring huge benefits to companies in terms of cost, time, effectiveness and efficiency. Good SCM allows you to improve the competitiveness and quality of services offered, reducing uncertainty. Around the 90s, companies felt that in order to better respond to market demand and new demands, which led to greater product personalization, however, due to the demand for the same delivery in a short time, it was necessary to try to reduce the product lead time while ensuring a certain level of adjustment [13].

Therefore, the concept of Supply Chain is broader than logistics as it refers to all activities that need to be carried out in an integrated and coordinated manner not only within the company but also with all systemic entities participating in chain flow management. It is represented by a network of companies that interact with each other to make the requested products and/or services available to end customers. It aims to manage the flow of goods and information unified across a single systemic entity that exists along the chain to leverage synergies between operators and avoid engaging in unnecessary, multiple and worthless activities, waste resources, and inefficiencies [14].

End customer satisfaction should represent the primary goal for which all actors in the chain must direct their efforts. The customer and his or her expected satisfaction represent triggers for the process of exchange and interaction between actors in the chain, and the outcome of this process evolves and for which actors act and interact. That is, the satisfaction of their needs must be the goal of every company that wants to win the competition [15].

Relationships in the Supply Chain are relatively stable, non -hierarchical and interdependent in the sense that what happens in the relationship has an impact on the content and processes of other companies belonging to the same chain. The division of labor causes, in fact, the interdependence of units and therefore requires flexible and decentralized coordination [16]. For example, a product upgrade requested by a customer can also result in a change in the specifications of materials used and components purchased by a customer's supplier from another manufacturer. Essentially, each organizational unit is partially dependent on resources controlled by other units, internal and external of the company; each unit can access the entire network resource based on its position in the same network [17].

\subsection{Why do SMEs Implement Supply Chain Management?}

The SC approach is used primarily as a way to gain a sustainable competitive advantage in the long run. Lussak et al [7] argued that partner firms in SC are not independent or dependent, but it is this interdependence and interdependence that makes transactions between these organizations bring unique results that cannot be copied by other SC networks. Parmar [18] stated that consumer pressure for low prices and high product quality causes companies to need to improve cost efficiency and lead time to gain a competitive advantage. SC will be a key factor in achieving this advantage. 
To get an edge over the competition, many companies are now focusing more on their supply chains and thus figuring out the best way to increase their offering in supply chain management [15]. Controlling the product flow from supplier to consumer is the goal of SCM. Supply chain management is also responsible for overseeing all processes taking place along the supply chain to remain competitive. Its main objective is to ensure efficient and accurate transportation of goods from the company to the consumer [18]. The main functions and responsibilities of supply chain management are environmental performance, quality control of goods and services from suppliers (inventory), management of delivery times, and improvement of product quality. products provided by the company [7].

Tambunan and Nofrian [19] also cited several other reasons for implementing SC, such as, for example, to reduce transaction costs, through lower recruitment costs and better communication coordination and control; gaining strategic impact, such as increased collusion or bargaining power; increased opportunities for price discrimination; reduction of uncertainty, both regarding prices and costs, supply of materials, customer demand, technology, etc. and, the potential for innovation in networking, through Research \& Development collaborations between companies. Thus, the key benefits of SC for SMEs are increased customer focus, cross -network competition, greater specialization in scale and scope, and reduced risk of cash flow shortages. On the benefits of SC implementation expected by SMEs, Kersten et al [17] mentioned that the supply chain can help these organizations to overcome the limitations imposed by resource innovation and cost reduction and uncertainty about supply, reducing mortality rates of these companies.

\subsection{Impact of Supply Chain Implementation on Smes Performance}

SCM practices tend to be used differently by SMEs and large organizations. Pavico [20] compared SC practices in terms of strategic and operational options, such as competitive priorities, key strategies, external control framework, internal control framework and SC process objectives. The discussion of SC for SMEs is closely related to the differences between small and large companies. SMEs, as opposed to large companies, differ not only in size but also in the way they are managed, which has implications for the way these companies manage their supply chains.

Pavico [20] argued that the competitive advantage of SMEs lies in their differentiation, i.e., in tailored services to customers, not factors such as price and cost, as is the case with large companies. In addition, the authors cite other features such as reliance on a number of customers and a limited number of competitors. According to research conducted by Ya'kob and Jusoh [26] said that micro and small enterprises have the following characteristics: capital intensity low, higher birth and dead rates, high labor for business, decision making good. centered.

As a result, often corporate ownership and family private ownership are confused in terms of accounting, use of unskilled or semi -skilled labor, low investment in technological innovation, greater difficulty in accessing funding for working capital, and complementary and subordinate relationships with large firms. Baymout [22] cited several positive or negative characteristics 
associated with SMEs versus large firms, which are highlighted in the literature. Regarding SMEs, the authors conclude:

1. SMEs do not have the capacity (resources, capital, production, etc.) to perform true vertical integration;

2. SMEs are more vulnerable in acquiring assets specifically for enterprise activities, resulting in "prisons" for SMEs that cannot easily decommission or liquidate assets to convert their production to meet chain requirements;

3. SMEs have high capital and transaction costs and contract costs, especially if it results in fixed investments;

4. SMEs are usually do not have the power to bargain with large companies;

5. SMEs have a low reputation in the market, suffer from a lack of trust, as most of them are young companies.

Over the past decade, both the literature and operational practice have shown a growing interest in integrating processes throughout the supply chain. Integrated supply chain management commonly known in Anglo -Saxon terminology as Supply Chain Management (SCM) - is called a key competitive advantage based on the well -demonstrated benefits that can be achieved through its implementation in terms of effectiveness, efficiency, operations. flexibility, level of customer service [22]. If the manufacturing context represents a special area of SCM analysis and application, the adoption of an integrated approach to supply chain governance can also be an important lever for MSME companies for the purpose of competitive advantage. The increasing complexity that characterizes the current competitive scenario also requires MSME companies to seek increasingly pressing opportunities to increase the level of flexibility, efficiency and quality of the process set required for production and provision of services to end customers [23].

The studies that have been done in the last decade show the changes in the sustainability of SCM from a minor topic in SCM to one of the big ones. According to the Council of SCM Experts (2012) in the United States, the planning and management of all activities includes procurement, conversation and all logistics management. Collaborative relationships between stakeholders, i.e. suppliers, are also included in supply chain management. Essentially, SCM integrates supply and demand management within and between the companies involved [24].

Baymout [22] stated that SCM is considered as a strategic to achieve purpose organizational such as better customer, profitability and increased competitiveness and even to increase organizational effectiveness. Kot et.al [30] state that the purpose of SCM is to maximize supply chain profits or surplus by controlling supply chain operations, resources, information, and funds. They also state that supply chain management is the difference between all the costs incurred by the supply chain while meeting customer order satisfaction and the revenue derived from customer orders.

Key components of SCM include supply chain management, product planning and design according to consumer needs, sourcing of all materials, manufacturing, product delivery to consumers and Return process for defective products. Since supply chain management's primary 
concern is the value of material costs and the efficiency of product delivery, all of these components are guaranteed to be up and running at all times. The products that consumers receive are of the highest quality at an affordable cost. does not weigh on producers and consumers. Studies have shown that SCM can correctly eliminate consumption costs and increase profits [25].

\subsection{Analysis of Interdependencies in The Supply Chain}

The phrase "Supply Chain", therefore, intends to emphasize the aspect of operational integration between all organizational entities given that the end result of the supply process is the result of the joint efforts of entities present throughout the chain. Compared to its original meaning, there has been an evolution in content over time and this is confirmed by the fact that today the concept of SCM involves "Integration of business processes that provide products, services and information they add value to their customers, from end users to end customers." with raw material manufacturers [16]. Therefore, SCM is configured as a network of organizations consists of, through the same up and downstream links, in various activities that value in the form of products or services aimed at end users [26].

In supply chain management there are 2 types, namely Upstream Supply Chain and Downstream Supply Chain [16] [21] [28]:

1. Upstream integration, as it involves the process of input by suppliers (suppliers of raw materials, semi -finished goods, services, consulting). The need to involve suppliers in the innovation process carried out by the focus company, to reduce the duration of the delivery cycle, to obtain relevant information about the evolution of technology and the behavior of competitors, to subcontract most of the production process to them (with respect to which the focus company cannot state specialized skills), causing the need for coordination between the focus company and the supplier to increase so as to make long -term agreements comfortable, the communication process more intense, the division of bodies aimed at managing together. decision -making process, development of trust relationships;

2. Downstream integration, i.e., the process of output to the customer company. Also, in this case the need to gather information, to strengthen customer loyalty, to involve them in the process of developing new products and services leads to more intense organizational relationship management.

Therefore, on the importance of sub-supply assumptions for focus companies, it is possible to identify two types of suppliers [1] [27]:

1. Tactical suppliers, these are suppliers of less important components, with which traditional contractual relationships are maintained. The cost of switching suppliers is low and sources of supply are often arranged in a multi -source logic, i.e., multiple supplies;

2. Strategic suppliers, these are key suppliers as they play a strategic role for companies that focus not only on production process efficiency, but also with reference to quality and innovation. 


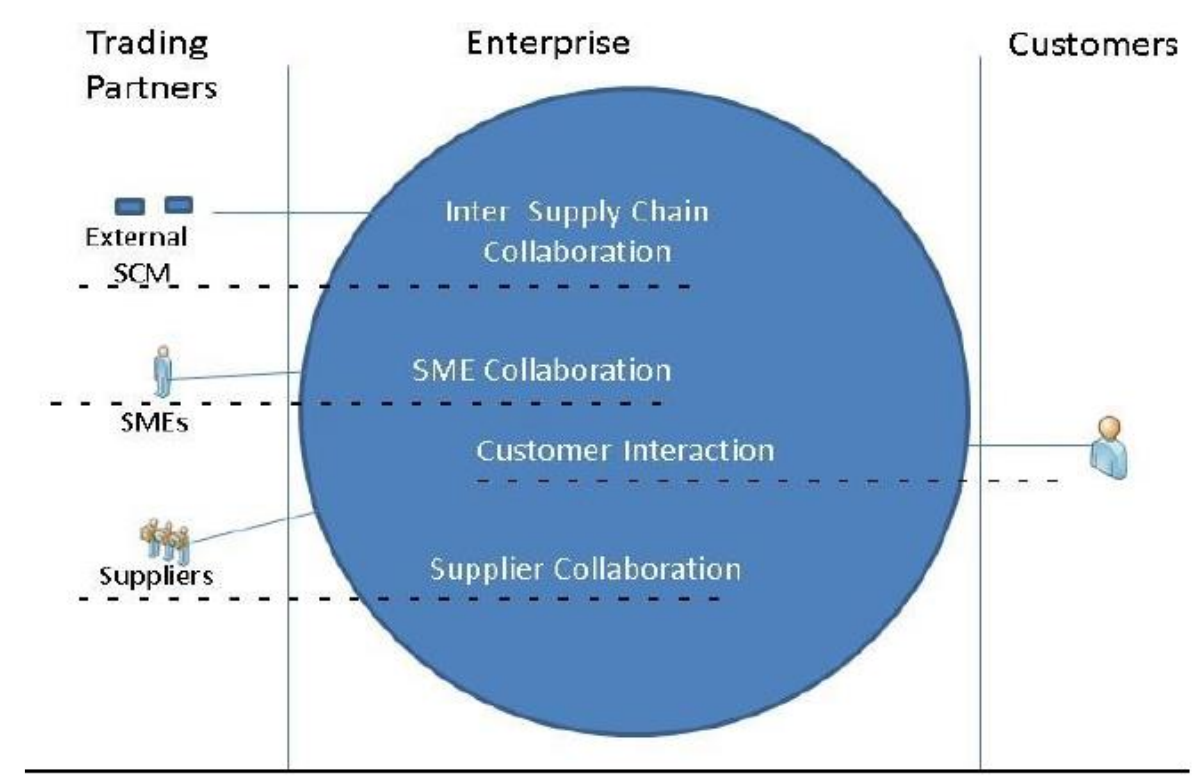

Figure 1 Supply Chain Collaboration Concept (Baymout, 2015)

\subsection{Supply chain collaboration.}

Supply chain collaboration is defined as two or more independent companies working together to design or perform activities. This can bring great benefits and advantages to the joint venture partner. This is called a synergistic strategy when one or more companies create benefits together [7].

There are two types of supply chain cooperation, vertical and horizontal cooperation. Collaboration while two or more corporations at different tiers or levels of the supply chain proportion their duties, resources, and overall performance records to provide services to virtually equal give up customers. It's a vertical partnership; while an inter-organizational relationship between two or more companies at the same or at the same level of the supply chain to allow easier work and collaboration to achieve common goals i.e., cooperation horizontal. There are many forms and approaches to supply chain collaboration [19] [21] [28] [29] [30] [31]:

1. Collaborative communication; is the method of contacting and sending messages between supply chain companions in terms of frequency, direction, modalities and strategies of impact. Open, common, balanced, two -manner and multi -stage verbal exchange suggests a near relationship between agencies.

2. Collaborative implementation; is the method of executing supply chain transactions collaboratively. The supplier will work with the consumer to make certain the correct quantity of material is introduced at the right time in step with the settlement. on the grounds that a purchase order spans its life cycle from order to delivery, near cooperation between business partners is required at every stage for proper and efficient execution.

3. Coordination contract; defined as a coordination mechanism that offers incentives to all its contributors so that a decentralized supply chain improves supplier-buyer relationships. 
4. Sharing information; is the quantity to which a corporation shares relevant, accurate, entire and exclusive units of ideas, plans and procedures with its supply chain partners in a welltimed manner.

5. Make decisions together; refers to the process by means of which supply chain companions control selections in supply chain making plans and operations that maximize supply chain benefits.

6. Creation of shared knowledge; is the degree to which supply chain companions expand competitive surroundings through working together.

7. Sharing resources; is the technique of leveraging capabilities and resources in addition to investing in abilities and sources with supply chain partners.

\subsection{Supply Chain Distribution}

The main objective of SCM is to increasing level of service to end customers, while optimizing costs and capital employed. It is important, in SCM projects consists of collaboration plays a key role. Through this collaboration some functions have been improved, such as [5] [7] [9] [11] [15]:

1. Demand forecasting, needed to better understand user needs;

2. Demand planning, to create a more reliable and accurate action plan and reduce the number of returns (return logistics);

3. Order Processing;

4. Planning of production capacity and therefore the optimal use of the plant;

5. Plan the use of materials;

6. Integration between supply and demand; and

7. Integration and cooperation between production, logistics and marketing

\section{Research Methodology}

The purpose of this research was to review the supply chain method literature from several past studies with reference to specific guidelines relevant to the context of past studies. one of the most critical steps in this research is that the survey is to decide the context of the literature review based totally on procedures and applications. This article reviews past studies related to supply chain implementation in SMEs, as well as reviews the literature to analyze how SMEs have implemented supply chain management approaches.

To understand the role of the supply chain in MSMEs, we conducted a comprehensive Literature Review, which resulted in the identification and analysis of 20 high -quality international journal articles, published between 2017 and 2021 in English were selected and analyzed. A systematic literature review was used as the survey methodology so that the survey could be explained systematically. The table presented is used in this research to investigate the results of previous studies related to the case research of the application of the Supply Chain concept in practice. this article focuses on articles aimed toward developing theoretical concept works, literature reviews in addition to case research into consideration. 
This article is organized into 5 sections, Section 1 contains an introduction containing the background of the urgency and importance of Supply Chain implementation by SMEs in the face of global competition in the 21 st century. Section 2 describes a review of the literature related to the concept of Supply. The chain and its integration with other approaches in increasing productivity. And revenue of the company. Section 3 presents the literature review methodology from several past studies that evoke case studies of Supply Chain implementation in several MSME companies. The case studies analyzed in this article are not limited to SMEs but also large -scale companies. In section 3, it also summarizes the results of a selection of several high -quality and Scopus -indexed international journals related to supply chain applications by MSMEs into a table. An in -depth analysis of several studies related to supply chain implementation in SMEs as well as in large -scale companies (including the advantages and disadvantages conducted by this research) summarized in the Table in Section 4 is presented in section 4. Finally, conclusions and future studies from this research provided in section 5 .

\section{Identified of Supply Chain Applications on Previous Literature.}

Seventeen case research appertain to the SCM in Small and Medium Companies has reviewed for analysis. These articles are reviewed in Appendix 1.

\section{Results and Discussions.}

As summarized in Table 1, some case studies related to the implementation of Supply Chain Application in SMEs have been selected for review in this study and this paper has summarized 18 international reviews for further analysis. Accordingly, the authors found major results in several earlier literary works, as discussed below.

Trong Lam Vua et al (2021) assessed the factors affecting financial flows and the influence of supply chain finance on supply chain finance and SME performance in Vietnam. They surveyed 1,000 SMEs using commercial bank supply chain finance. The list of SMEs is collected from the credit department of commercial banks. The studies variable scale changed into evolved from preceding research and changed to healthy the context of SMEs in Vietnam and industrial banks in Vietnam. All scales are measured through the belief of SMEs using a five-factor Likert scale with 1 strongly disagree and five strongly agree. This study offers solutions and suggestions to help small and medium-sized organizations higher get right of entry to capital and improve their enterprise overall performance. therefore, to promote this market to broaden deliver chain financial services, factoring desires to be blanketed in cutting-edge felony documents. monetary supply chain market transparency and authentication will assist Vietnam sell the prosperity of businesses, especially SMEs.

Demberee \& Richard (2021) studied the effectiveness of deliver chain control practices withinside the production of micro, small and medium enterprises (SMEs) in Zambian country. To expand the reseearch, they used a descriptive studies layout and selects a questionnaire shape as a records series tool. Sampling strategies are used to reap records from the control and workforce of SMEs. 
One hundred questionnaires have been allotted to the respondents. The records received have been then analyzed the usage of descriptive techniques. This article advanced a conceptual framework that describes the proposed dating among product quality, flexibility, reliability, transport velocity and cost, that's taken into consideration a precursor to SCM practices. Primary records have been accumulated the usage of a questionnaire administered alone. The questionnaires have been organized consistent with the targets of the studies. To guide their studies, this text decided on SMEs withinside the Mandevu and Kalingagalinga Lusaka markets engaged in production activities (steel and timber fabrication). Descriptive statistical records evaluation techniques have been used and records presentation turned into completed the usage of frequency tables and graphs. This article concluded that SMEs withinside the studies regions have a slight understanding $(41 \%)$ of the idea of deliver chain control, this could be one of the motives there are terrible SCM practices. Feedback from SMEs showed that get entry to loans and financial institution finance stays the largest trouble for SMEs in Zambia. It has been decided that inadequate capital to begin and keep a commercial enterprise is a main project hindering the increase of this zone as $57 \%$ of respondents rated this project as being taken into consideration as important to very large.

Okoumba \& Mafini (2021) analyzed the connection between SCM method, supply chain agility and supply chain overall performance amongst SMEs in South Africa. This has a look at tested the connection among SCM, SCA and SCP activities in SMEs in South Africa. This study also demonstrates the importance of implementing SCM practices in South African SMEs. The populace used in this look at includes proprietors, managers and expert employees of small and medium-sized groups running in Gauteng, South Africa. The use of sampling techniques in this article is intended to help select only relevant respondents for research. To be decided on, respondents must have at least "matrix" education and familiarity with the SCM concepts considered on this look at. The very last sample of 407 respondents was selected for correlation or regression analysis. The data amassed on this have a look at were analyzed the usage of the social technology Statistical bundle (SPSS version 25.0). the main records used on this look at encompass exploratory thing evaluation (EFA), Pearson's correlation and regression analysis. The validity of the structure was first tested using the factorial saturation obtained in the EFA procedure. Reliability refers to the volume to which measurements are error-unfastened and for that reason produce steady effects (Ang 2014). The reliability of the work is checked by means of Cronbach's alpha coefficient. This observe suggests that agility in SMEs results in better pcs, therefore, new organizations want to cognizance on growing the ability to reply quick to environmental adjustments as a manner to improve their operational performance.

Mahmud et al. (2021) attempted to develop a decision modeling framework to analyze the constraints of CCS in SMEs for the developing economy in Bangladesh. This study uses SMEs in Bangladesh as survey subjects. The important contribution of SMEs to the Bangladeshi economy is the main reason to use Bangladesh as the context for this study. This study tried to fill the research gap by collecting the barriers of CCS in different SME sectors in Bangladesh and evaluating using different MCDM techniques. They argue that this technique will help distinguish 
how SMEs in developing countries face difficulties in implementing CCS compared with SMEs in developed countries. This study uses a questionnaire-based survey to select the most appropriate SCC barriers for SMEs in Bangladesh. This study has pointed out the importance of CCS-related information and communication barriers among Bangladeshi SMEs. Lack of communication is the biggest obstacle that SME managers should focus on.

Lussak (2020) analyzed the strategic influence of Triple A supply chain in improving supply chain performance for small and medium enterprises (SMEs) operating in the food and beverage sector in Semarang city. In this study, the supply chain performance of SMEs involved in the food and beverage sector in Kota Semarang, Central Java is used as the dependent variable, while the independent variables are used. in this study are adaptability, alignment and agility. This study used data from a questionnaire distributed directly to respondents, i.e., SME managers in the food and beverage sector in Semarang city with 50 respondents. This study summarizes: First, the agile variable has no positive and significant impact on supply chain performance. Second, the adjusted variable has a positive and significant effect on supply chain performance. Third, the linkage variable has a positive and significant impact on supply chain performance. Fourth, variable Ba A has a positive and significant concurrent impact on the supply chain performance of SME agribusinesses in Semarang city.

Lutfi \& Buntuang (2020) presented a study titled Impact of social distancing policy on small and medium enterprises (SMEs) in Indonesia. This study aims to determine the impact of the social prison policy on SMEs in Indonesia using a quantitative method and survey design. This study uses a quantitative method with a survey design, and conducts a survey of SMEs in Indonesia regarding the implementation of the social prison policy. Data were collected through questionnaires, observations, and literature reviews. The sample is selected at random. Data from this study were analyzed using descriptive statistics with SPSS. Descriptive statistics that describe the study sample are statistically summarized in a valid and meaningful way. This study concludes that most of the respondents are businesses affected by social distancing policies. The COVID19 pandemic has taken a heavy toll on the business community. This reduces revenue due to reduced demand and troubled supply chains, increasing raw material and production costs during the pandemic. This study also summarizes that the issues that have arisen during the COVID19 pandemic show that the COVID19 pandemic has greatly affected the sustainability activities of SMEs in Indonesia and other countries. This reduces demand for products for SMEs, affecting their financial position (Cash Flow), which ultimately prevents SMEs from paying credit, interest and even taxes.

Omar et.al (2020) proposed a descriptive and qualitative method to examine the impact of the Covid19 Movement Control Order (MCO) on small and medium-sized businesses and identify the strategies that exist. based on the owner's point of view. This study uses a qualitative approach conducted through telephone interviews with six selected SME "owners". They argue that qualitative research does not attempt to generalize findings to a larger population. In addition, this study attempts to analyze the impact of OLS on SMEs classified into operational issues (i.e., The 
study interviewed six selected subjects who were participating in the activities. different businesses). This study summarizes that there is consensus among respondents that the main theme of existing strategies currently concerns financial and marketing strategies that utilize all valuable resources and strategies. strategy under their control.

Filho \& Moori (2020) attempted to evaluate Supply Chain Management (SCM), Strategic Management (SM) and Resource Based Perspective (RBV) as the foundation for business performance (BP). This study used SCM to streamline key businesses to achieve flows of tangible and intangible assets that effectively respond to customer needs and wants, providing feedback throughout the entire chain. The exploratory technique used in this study is divided into two phases: qualitative, which promotes a better understanding of companies associated with Brazil's technological poles, and validation of size and scale. The model is developed for each theoretical model building. 125 Sample of companies in Brazil were selected for the object of this research. In this research, data from semi -structured interviews with managers are processed using content analysis methods, then tabulated the data through Microsoft Excel ${ }^{\circledR}$ and processed it using SPSS ${ }^{\circledR}$ software (Statistical Package for Social Sciences) version 21.0 for descriptive and multivariate techniques. Finally, Smart PLS® software version 2.0 is used for Structural Equation Modeling (SEM). To validate the scale and construction scale of the model, Filho \& Moori used validation factor analysis, which allows the adjustment between the observed data and the theoretical model, and identifies the pseudo-causal relationship. between the latent factor (unobservable variable) and its indicator variable. (observable). The results of this study summarize that the variables that contribute the most to explaining the performance of firms in national technology centers are: human resources and organization, RBV and in SCM, Market forecasting, inventory management and multi-product planning activities are developed with members of the supply chain. We emphasize that the company's performance is more influenced by higher gross margin, higher sales and larger market share variables.

Baig et al (2020) tried to identify the main obstacles hindering the implementation of sustainable supply chain management practices and corporate performance on three key points and the impact of scale What is the company to overcome these obstacles. This study uses six hypotheses to identify classification barriers in the context of the Pakistani textile industry through exploratory factor analysis (EFA) which has rarely been investigated in the previous literature, and is empirical and statistical tests as well as to substantiate the 'impact of the identified barrier types. The data used in this study were collected from a textile processing company, is a member of Pakistan Textile Manufacturers Association and All Pakistan Textile Manufacturers Association located in Faisalabad city, the heart of the textile industry in Pakistan. This study exposes external stakeholders such as the media, NGOs, the public and activists, etc. can also influence textile organizations to become part of a sustainable community. Factors within the organization can also be understood to initiate programs related to sustainability management practices.

Shahbazi et.al (2019) surveyed online shopper in Lithuania to determine factors that influence consumer' decision over online shopping. A web-based questionnaire survey was used for data 
collection. Theirs focused on analyze e-commercial advantages like security, cheaper prices, comparable prices, fast delivery, convenience, and wide choices. This study reports that people choose to shop online because of their convenience and simplicity, and socio-demographic characteristics also show that women frequently participate in online shopping for products with prices are lower than men, and shopping is quick and convenient.

Shahbaz et.al (2019) in their study tried to focus on seven empirically validated supply chain collaboration approaches, that is, information sharing agreements about vision and goals, supplier-customer relationships, information quality, delays, and the sharing of risks and rewards in the supply chain. performance. Independent variables such as information sharing, agreed vision and goals, Risk/reward sharing, Information quality, Supplier relationship, Customer relationship. Postponement, and Dependent variables such as Supply chain performance were identified in this research. Shahbaz et.al concluded that all Supply Chain Collaboration (SCC) all SCC approaches have a positive impact on SCP for Malaysian manufacturing. The SCC approach had a positive and significant effect on SCP. RR and POS also had a positive but insignificant effect on SCP. POS is important but only for certain industries, not because delaying customers will be unsatisfactory and will also increase costs. While the impact of RR was not significant as suppliers and customers were hesitant to share risky information.

Nkwabi (2019) in his study is to measure variables such as technological difficulties, resources, lack of government support, need for information sharing, poor knowledge of SCM, poor coordination with suppliers, funds, go to market and support senior management, inventory management and skills shortages. working to identify frequently cited constraints affecting SCM implementations, followed by descriptive statistics. Nkwabi argues that the mixed methods approach in his study is appropriate because it allows the researcher to fully investigate existing phenomena. Therefore, the researchers claim that these methods can gather information about the limitations of MCS implementation through reviewing the literature and then testing descriptive statistics in terms of frequency and percentages, and allows the researcher to measure the relationship between the constraints and the overall implementation of SCM for PME analysis. This study summarizes that technological difficulties, cooperation problems, lack of senior management support and insufficient funding are the important factors affecting the effective implementation of GCS in different regions. Tanzania's small and medium enterprises.

Hamiza \& Isoh (2019) tried to analyze the relationship between SCM practices and SME performance in Arua, Uganda, in their research. This research proposes four hypotheses: First, H1: Supply chain collaboration is significantly positively correlated with the performance of SMEs. Second, H 2 internal management significantly affects the performance of SMEs. Third, H3: IT integration in SCM is significantly positively correlated with the performance of SMEs. Fourth, H4: Innovative SCM is positively and significantly correlated with the performance of SMEs. This study adopted a simple stratified random sampling technique when determining the research sample. The purpose of collecting key data is to investigate the impact of supply chain management practices on the performance of SMEs. Use a five-point questionnaire to collect data, 
ranging from strongly disagree to strongly agree with closed-ended questions. Hamiza \& Isoh summarized $\mathrm{Su}$

Mishra et.al (2019) in their article "Impact of SMEs Green Supply Chain Practice Adoption on SMEs Firm and Environmental Performance", attempted to analyzed the effect of the adapt of SMEs green supply chain practices on SMEs enterprises and environmental performance. This research revealed that the impact of green purchases on SMEs enterprise performance and environmental performance impacts the environmentally friendly design on SMEs enterprise performance. In this research, the descriptive analysis of SMEs was identified for this research. Mishra et.al (2019) were also argued that Green-friendly purchasing have a positive impact on SMEs as well as environmental performance. Addition, Green-friendly design has also a positive impact on the performance of SMEs but not environmental performance.

Kot et.al (2018) on their research applied the questionnaire was divided to identify the part and the substantive part pertaining to the SCM. level Likert value was used to examine the SCM concept in Polish and Romanian SMES enterprises, with the object of the research to evaluate the concept of SCM in Romanian and Polish SMEs, especially to identify the sameness and differences in the approaches to the concept of SCM. However, this research has a back draws regarding to number and choice of industries and company size.

Rezaei \& Ortt (2018) on their articles attempted to check the partnerships business functions, and also investigation the drivers and performance impact of these partners for each business function. The data in this research were collected on four business function partnerships (marketing and sales, R\&D, purchasing and logistics, and production) using a survey of 279 high -tech SMEs. The Structural Equation Modeling (SEM) was used to investigate the hypothetical relationship between functional partnerships and performance of the functions, and also between the drivers and the functional partnerships. The population of this research is Dutch SMEs in high-tech industries. This research used SEM method with LISREL 8.80 that was devided into four steps: First. Model specification. Second, Model identification. Third, Model estimation, and Fourth, Model testing and modification. Also, Confirmatory factor analysis consists of two steps: First, the measurement model should be evaluated to check the suitability of the model, and second, the structural model should be examined.

Chopra \& Kaur (2018) conducted research to analyzed the effect of SCM on the operational availability. Furthermore, this research attempted to research the role of SCM barriers performance the SMEs in India. population analyzed in this research were consists of all of SMEs related to the manufacture of all types of publishing, pharmaceuticals, printing, food and beverage products. agricultural products, biotechnology, and machine tools, Chopra \& Kaur (2018) applied Factor Analysis (FA) to exploration the factors, this rooting a relationship the observed variables and the factors. The purpose was to reduce the number of variables, and determine the factors number that underlining the construct. Chopra \& Kaur (2018) concluded that Supply Chain has a significant and positive impact on the operational performance of SMEs in India. They also summarized that there is a strong relationship between Supply Chain barriers and operational 
performance of SMEs in India. Additional, to increase the SMEs in India, as a result, the managers should be focus on develop the relationships with customers and suppliers.

Epoh \& Martini (2018) surveyed 65 SMEs in South Africa country, especially in Gauteng Provimce. Data were collected using questionnaires with samples ranging between 50 and 600 respondents. The SPSS version 24.0 and the AMOS version 24 were adopted as data analysis. This research examines three variables; First, Predictor variables which were consist of Quality (products, process quality, and product practices). Second, mediating variables which were consist of Environmental performance, and Third, Outcome variables which were consist of Supply chain performance. Epoh \& Martini claimed that their research has the Green Supply Chain's positive contribution to the environmental performance. Addition, lead to management implications, which was focus on how Green Supply Chain practices can be leveraged the performance improvement in SMEs in South Africa country.

\section{Conclusion}

This research further concluded of Supply Chain on SMEs. Based on the literature discussion, this article can be stated several factors that facilitate or barriers in implementation of Supply Chain in (SMEs), i.e., the use of information technology, wide perceptive of communication between Supply Chain partnership companies, support from large organizations and alignment between business planning and Supply Chain Management. Between the barrier's factors, this research has revealed the focus on the short term, limited time, resources, knowledge, and and failure to overcome the traditional competitive perspectives to become more collaborative. This research also revealed that based on analyze of 31 international articles from previous research which were applied the integration SCM on SMEs, we highlight several identified variables most common adopted: SC performances, SC barriers, SC information sharing, SC partnership, and information technology.

This research contributes to the literature in offering an overview of supply chain relationships in a more systematic way. Understand what has been implemented in terms of supply chain relationships in M/SMEs. This research particularly important as present the information on the effect and impact of SCM integration on M/SMEs performance. Also, this research is essential to examine how an improve SCM can improve the quality of delivery of goods and services by M/SMEs.

However, limitations that should be addressed in future research. This understanding is critical because globalization creates multiple players along the supply chain, who are used to more complex and challenging tasks to managed. Although electronic keyword search is widely recognized as the best and most common method for conducting systematic analysis, additional search techniques are recommended for researchers instead of electronic keyword search to find existing research papers, such as reference checking, i.e. the process of searching for additional papers in the reference list in at the end of the selected paper, citation searching, which is the process of identifying potential or additional papers by making use of the citation network that 
surrounds the original paper and consulting with experts if the researcher is unsure about the literature.

\section{REFERENCES}

[1] T.L.Vua, D.N. Nguyenb, T.A. Luongc, T.T.X. Nguyend, T.T.T. Nguyene, and T.D.U. Doane. "The impact of supply chain financing on SMEs performance in Global supply chain”, Uncertain Supply Chain Management 10, pp. 1-16. 2021.

[2] J. Demberere, K.M. Richard. "The Effectiveness of Supply Chain Management Practices On Manufacturing Micro, Small And Medium Enterprises (Msme) In Lusaka: A Case Of Mandevu And Kalingalinga Markets Global”. Journal of Purchasing and Procurement Management, vol. 1, no. 1, pp. 1-21. 2021.

[3] W.V.L. Okoumba and C. Mafini. "Supply chain management antecedents of performance in small to medium scale enterprises", South African Journal of Economic and Management Sciences. ISSN: (Online) 2222-3436, (Print) 1015-8812, pp. 1-13, 2021.

[4] P. Mahmud, S.K. Paul, A. Azeem, and P. Chowdhury, "“Evaluating Supply Chain Collaboration Barriers in Small- and Medium-Sized Enterprises," Sustainability, 13, 7449. https://doi.org/10.3390/su13137449, pp. 1-28. 2021.

[5] S. Kot, I.R. Goldbach, B. Slusarczyk. "Supply Chain Management in Smes Polish and Romanian Approach”, Economics \& Sociology, vol. 11, no. 4, pp.142-157. 2018.

[6] J. Rezaei and R. Ortt. "Supply Chain Drivers, Partnerships and Performance of HighTech SMEs- an Empirical Research Using SEM, Productivity and Performance Management, vol. 67, no. 4, pp. 629-653. 2018.

[7] A. Lussak. "Triple A Strategy to Improve Supply Chain Performance in Semarang City SMEs" International Journal of Scientific \& Technology Research, vol. 9, no. 1, pp. 218223. 2020.

[8] M. Bedi and P. Chopra. "An Assessment of Impact of Supply Chain Management Practices on Operational Performance in Micro, Small and Medium Enterprises (MSMEs) in India", Amity Journal of Operations Management, vol. 3, no. 1, pp. 26-34. 2018.

[9] O. Hamiza and A.V.M. Isoh. "Supply Chain Management Practices and SME Performance in Arua Municipality, Uganda", Business Management and Strategy, vol. 10, no. 2, pp. 163-181. 2019.

[10] M. Lutfim, P.CD. Buntuang, Y. Kornelius, Erdiyansyah, B. Hasanuddin. "The impact of Social Distancing Policy on Small and Medium-Sized Enterprises (SMEs) in Indonesia”, Problems and Perspectives in Management, vol. 18, no. 3, pp. 491-504. 2020. 
[11] V.A.V. Filho and R.G. Moori. "RBV in A Context of Supply Chain Management", Gestão \& Produção, vol. 27, no. 4, pp. 1-20, 2020.

[12] S.A. Baig, M. Abrar, A. Batool, M. Hashim and R. Shabbir. "Barriers to The Adoption of Sustainable Supply Chain Management Practices: Moderating Role of Firm Size", Cogent Business \& Management, vol. 7, pp. 1-20. 2020.

[13] M.S. Shahbaz, F.A. Shaikh, M.A. Quresh, Q.B. Jamali, S. Sohu. "The Influence of Supply Chain Collaboration on Supply Chain Performance for Malaysian Manufacturing Industry", Journal of Organizational Behavior Research, vol. 4, pp. 203-218. 2019.

[14] J.M. Nkwabi. "Supply Chain Management Constraints in Tanzanian Small and Medium Enterprises", African Journal of Business Management, vol. 13, no. 16, pp. 564-570. 2019.

[15] A.O. Ogunyemi. "Competitive Strategies to Improve Small and Medium Enterprise Sales", Walden Dissertations and Doctoral Studies, Walden University, 2020.

[16] Heslina, O.R. Payangan, M.I. T, and M.I. Pabo. "Factors Affecting the Business Performance of the Micro, Small and Medium Enterprises in Creative Economic Sector in Makassar, Indonesia", Scientific Research Journal (SCIRJ), vol. 4, no. 1, pp. 41-50. 2016.

[17] W. Kersten, T. Blecker, C.M. Ringle. "Digitalization in Supply Chain Management and Logistics" Proceedings of the Hamburg International Conference of Logistics (HICL), no. 23, pp. 1-534. 2017.

[18] N.K. Parmar. "Analysis Of Barriers for Implementing Green Supply Chain Management In Small and Medium Sized Enterprises (SMEs) of India", International Journal of Humanities and Management Sciences (IJHMS), vol. 4, no. 3, pp. 1-5. 2016.

[19] T. Tambunan and F. Nofrian. "Does Trade Facilitation Really Matter for the Growth of MSMEs' Export? The ASEAN Case", Journal of Small Business and Entrepreneurship Development, vol. 5, no. 2, pp. 22-38. 2017.

[20] L.P. Pavico. "The Relationship of Supply Chain Management Practices of Micro Enterprises to Competitive Advantage", Review of Integrative Business and Economics Research, vol. 5, no. 4, pp. 92-107. 2016.

[21] A.R.C. Omar, S. Ishak, M.A. Jusoh. "The Impact of Covid-19 Movement Control Order on SMEs' Businesses and Survival Strategies", GEOGRAFIA Online TM Malaysian Journal of Society and Space, vol. 16, no. 2, pp. 139-150. 2020. 
[22] M. Baymout. "Supply Chain Management for Small and Medium Size Enterprises", International Journal of Advancements in Research \& Technology, vol. 4, no. 5, pp. 2035. 2015.

[23] LR. Epoh, C. Mafini. "Green supply chain management in small and medium enterprises: Further empirical thoughts from South Africa," Journal of Transport and Supply Chain Management, pp. 1-12. 2017.

[24] M.K. Mishra, D. Choudhury, K. S. Venu, G. Rao. "Impact of SMEs Green Supply Chain Practice Adoption on SMEs Firm and Environmental Performance", Theoretical Economics Letters, pp. 1901-1913. 2019.

[25] K.M. Radzi, M.N.M. Nor, and S.M. Ali. "The Impact of Internal Factors on Small Business Success: A Case of Small Enterprises under The Felda Scheme", Asian Academy of Management Journal, vol. 22, no. 1, pp. 27-55. 2017.

[26] S.A. Ya'kob and W.J.W. Jusoh. "The Effect of Supply Chain Linkage on Micro and Small Enterprises' Performance", International Journal of Business and Society, vol. 17, no. 1, pp. $99-112.2016$.

[27] J. Ali. "Performance of Small and Medium-Sized Food and Agribusiness Enterprises: Evidence from Indian Firms", International Food and Agribusiness Management Review, vol 19, no. 4, pp. 1-12. 2016.

[28] M.B. Ladeira, P.T.V. de Resende, M.P.V. de Oliveira, K. McCormack, P.R. de Sousa, R.L. Ferreira, Gest. "The Effects of Analytical and Business Process Orientation Approaches the on Performance of Small and Medium Industrial and Service Enterprises in Brazil", Prod., São Carlos, vol. 23, no. 3, pp. 486-502. 2016.

[29] M. Hudnurkar, S. Jakhar, U. Rathod. "Factors Affecting Collaboration in Supply Chain: A literature Review", Procedia - Social and Behavioral Sciences, vol. 133, pp. 189-202. 2014.

[30] S. Kot, "Supply Chain Management in SMEs Polish and Romanian Approach", Economics and Sociology, vol. 11, no. 4, pp. 142-156.

[31] J. Pradabwong, C. Braziotis, K. S. Pawar, and J. Tannock. "Business Process Management and Supply Chain Collaboration: A Critical Comparison”, Logist. Res, vol. 8 , no. 6 , pp. 1-20. 201 


\section{Appendix - 1}

\begin{tabular}{|c|c|c|c|}
\hline 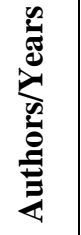 & 高 & 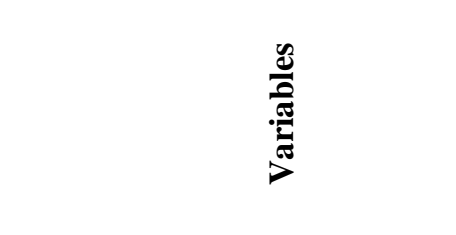 & 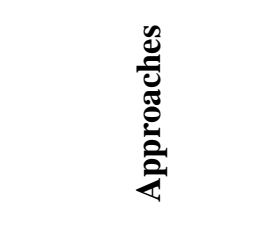 \\
\hline 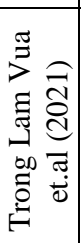 & 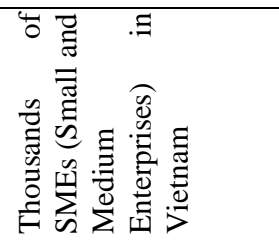 & 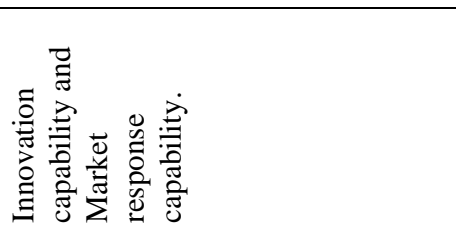 & 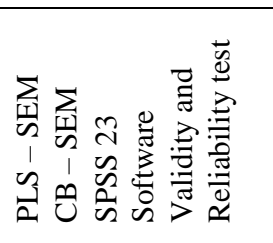 \\
\hline 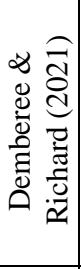 & 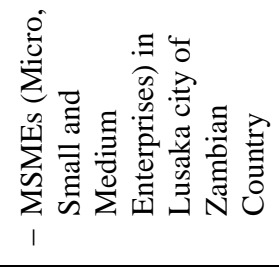 & 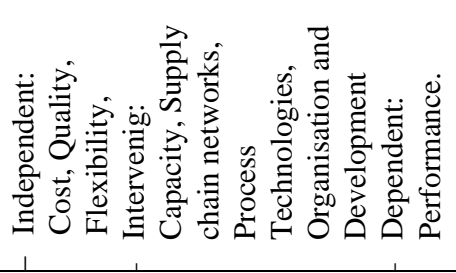 & 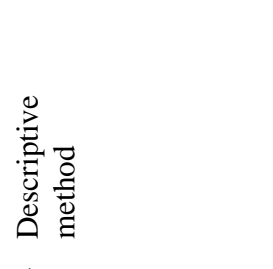 \\
\hline 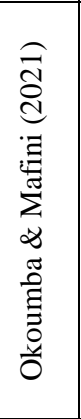 & 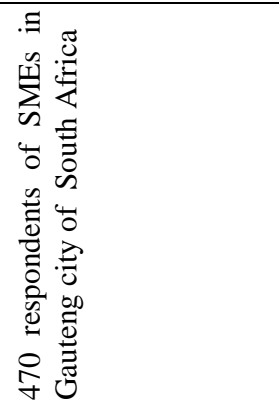 & 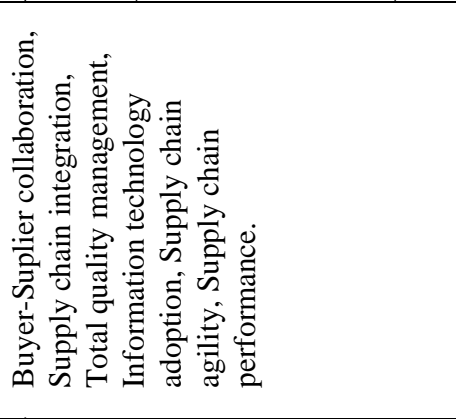 & 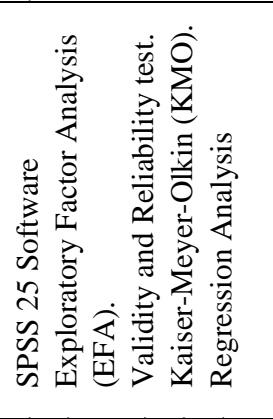 \\
\hline 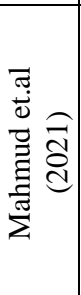 & 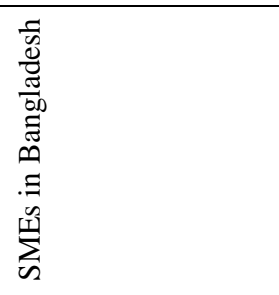 & 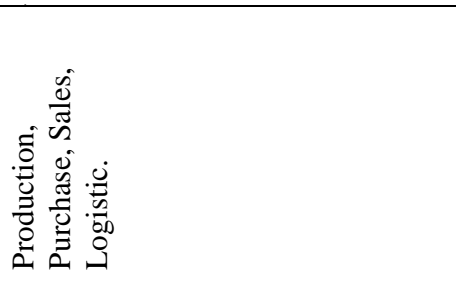 & 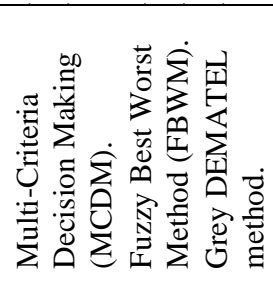 \\
\hline 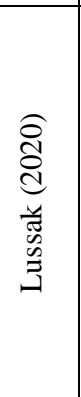 & 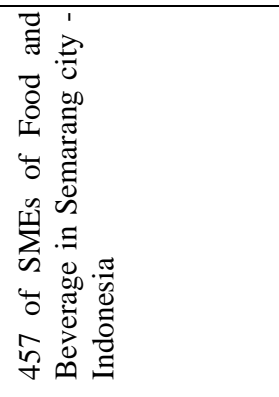 & 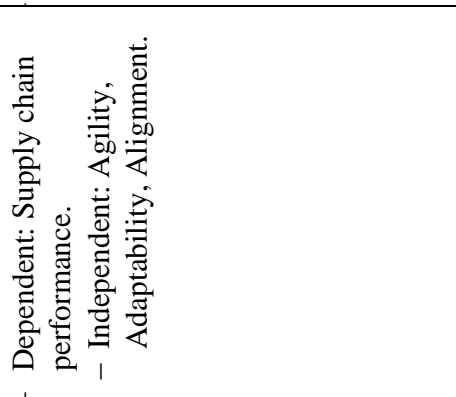 & 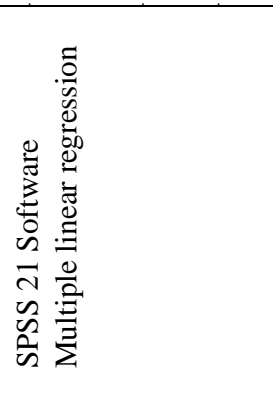 \\
\hline 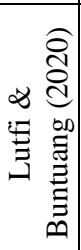 & 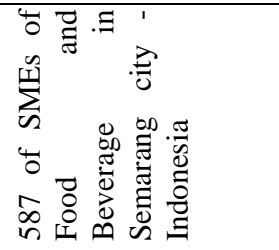 & 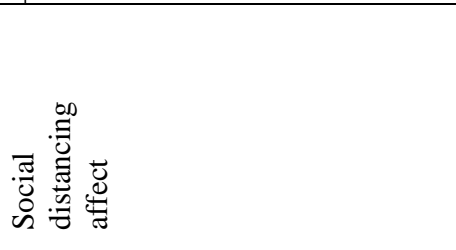 & 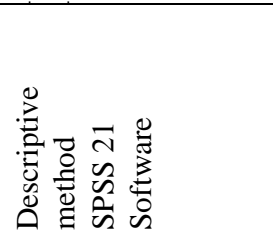 \\
\hline
\end{tabular}




\begin{tabular}{|c|c|c|c|}
\hline 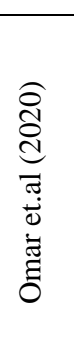 & 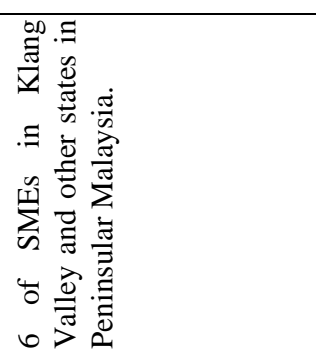 & 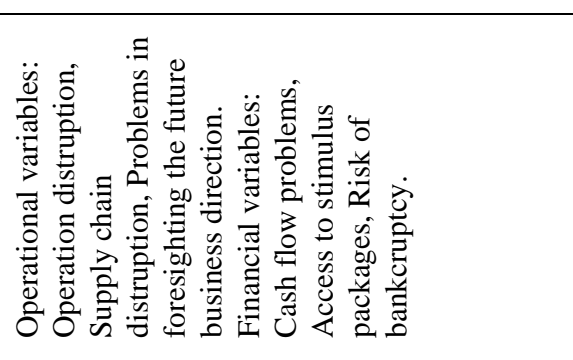 & 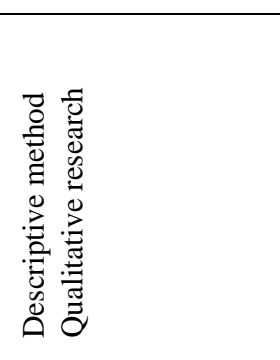 \\
\hline 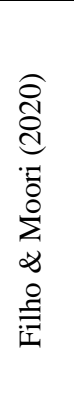 & 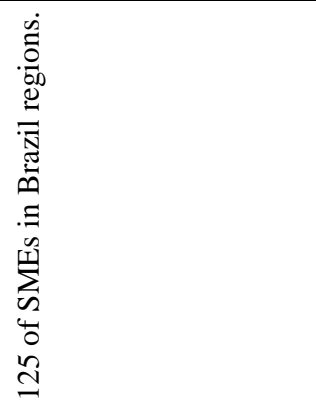 & 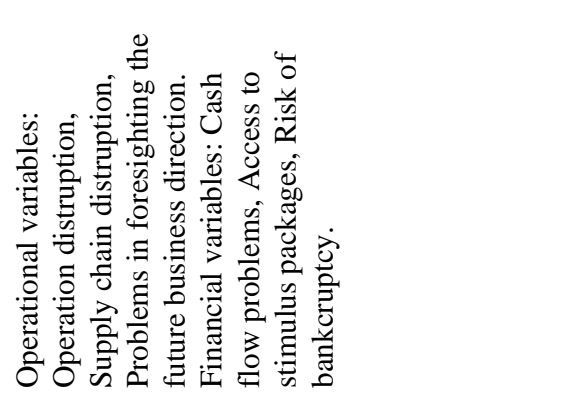 & 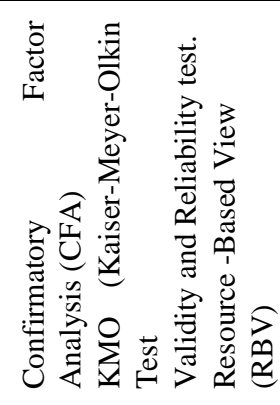 \\
\hline 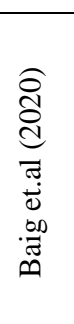 & 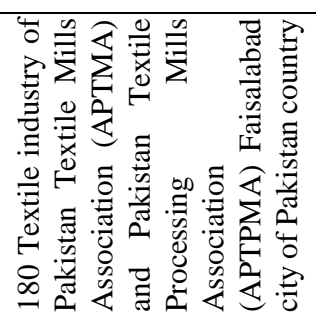 & 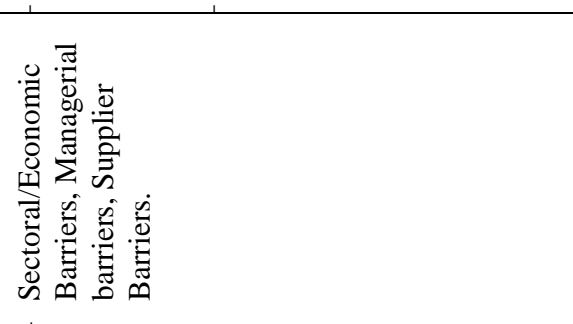 & 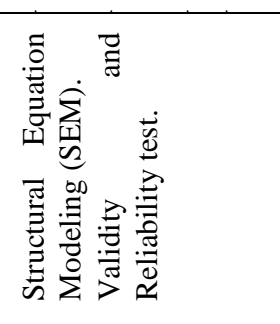 \\
\hline 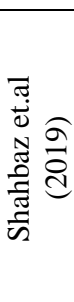 & 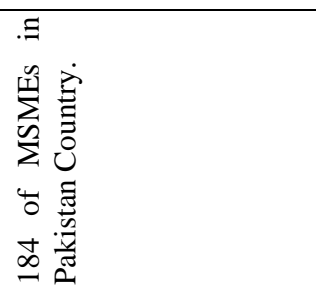 & 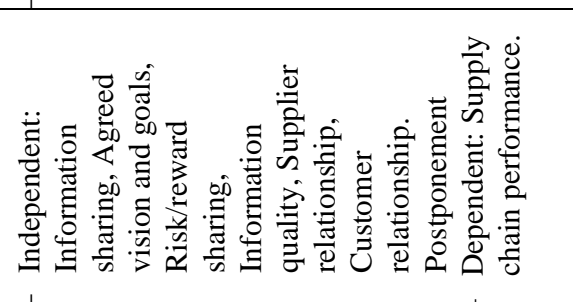 & 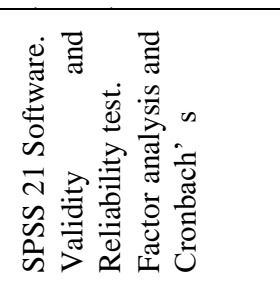 \\
\hline 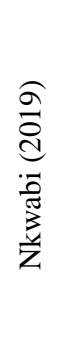 & 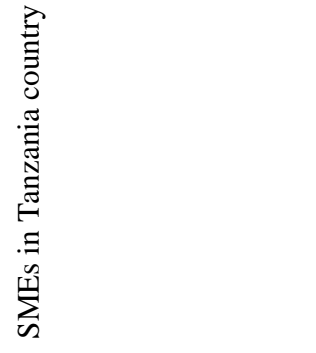 & 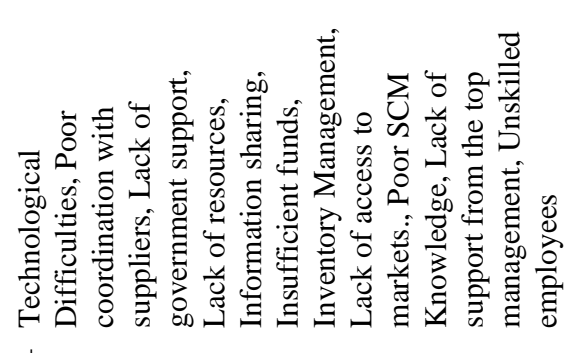 & 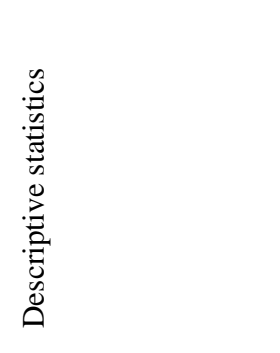 \\
\hline 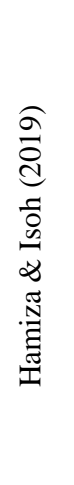 & 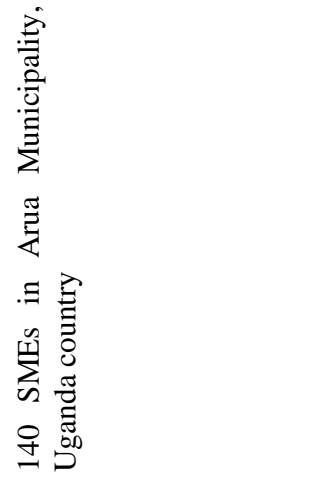 & 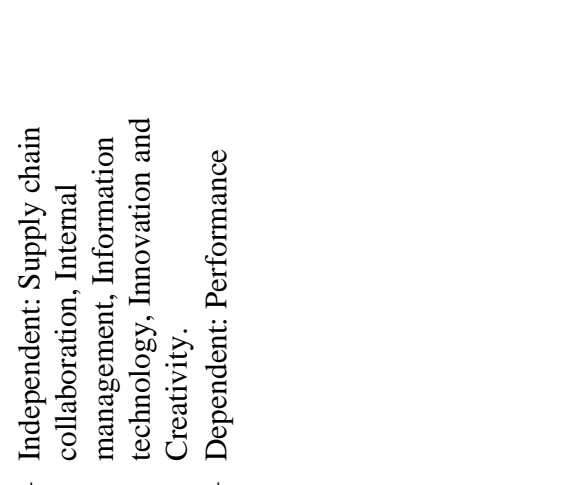 & 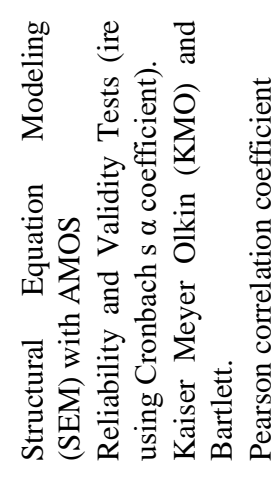 \\
\hline
\end{tabular}




\begin{tabular}{|c|c|c|c|}
\hline 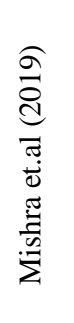 & 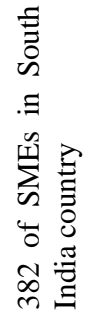 & 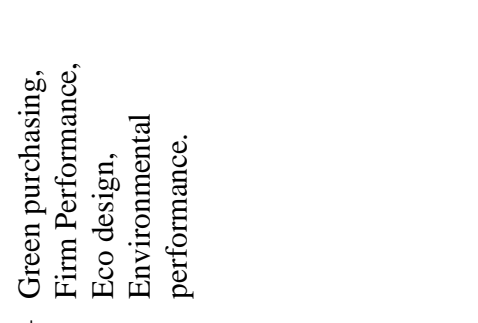 & 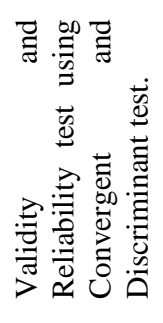 \\
\hline 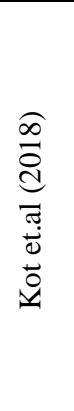 & 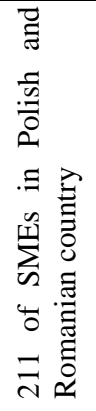 & 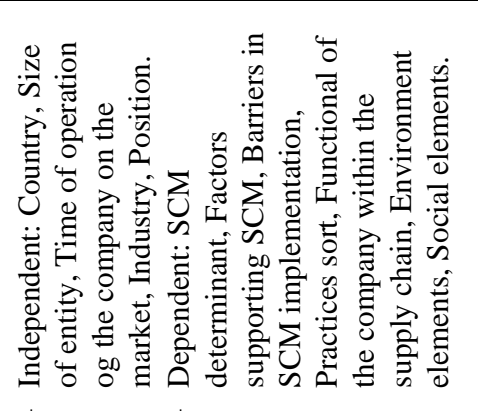 & 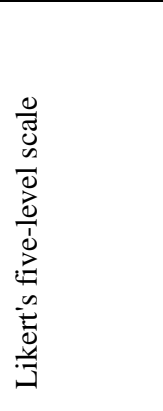 \\
\hline 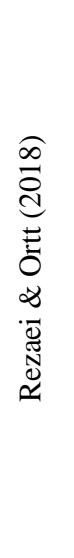 & 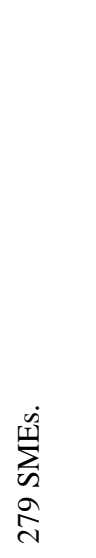 & 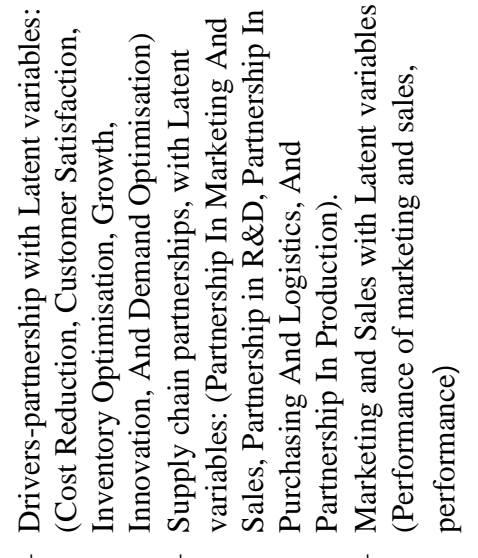 & 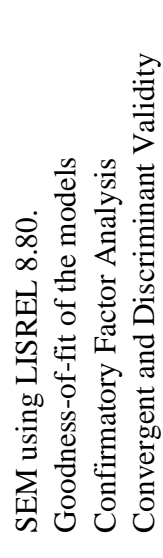 \\
\hline 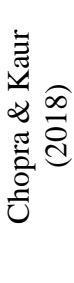 & 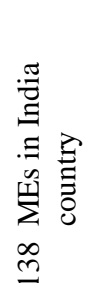 & 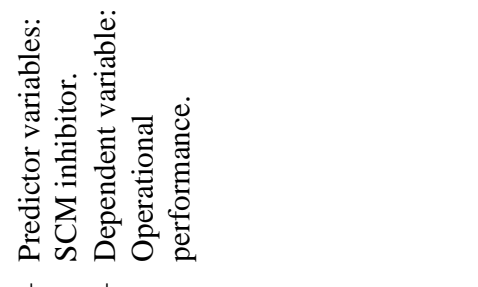 & 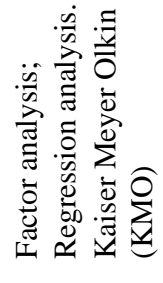 \\
\hline 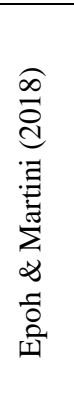 & 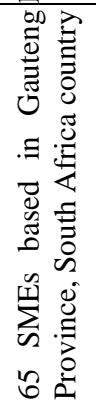 & 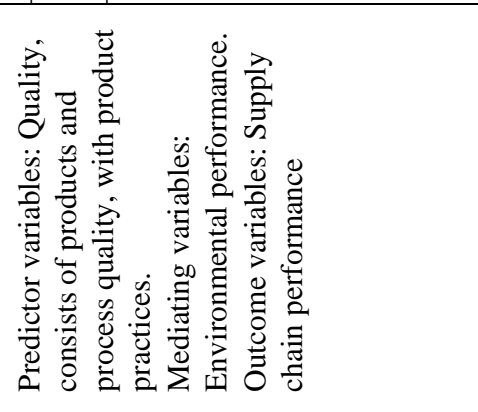 & 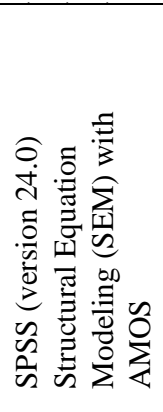 \\
\hline
\end{tabular}

